\title{
A Review on Epigenetic Effect of Heavy Metal Carcinogens on Human Health
}

\author{
Sanjay Mishra ${ }^{1, *}$, Surya Prakash Dwivedi ${ }^{1}$ and R.B. Singh ${ }^{2}$ \\ ${ }^{I}$ Department of Biotechnology, College of Engineering \& Technology, IFTM Campus, Delhi Road, Moradabad 244 001, \\ $U P$, India \\ ${ }^{2}$ Halberg Hospital \& Research Center, Civil Lines, Moradabad 244 001, U.P., India
}

\begin{abstract}
Cancer is a leading cause of morbidity, mortality, and premature death worldwide. Certain strategies for minimizing carcinogenic factors' exposure can reduce the risk of most cancer types in human. Millions of people around the world get exposed to high levels of heavy metals in the drinking-water. Therefore, quality control in drinking-water and detection of its heavy metals is extremely critical issue in maintaining the human health. The carcinogenicity of aluminum, arsenic, chromium, nickel and selenium has been documented previously, but in scattered fashion. Trace amount of these elements entering the body via various routes can induce genetic and epigenetic alteration in different cancer related genes of somatic and stem cells, thus involving in cancer stem cell formation. Epigenetic variations in the etiology of cancer have led to increasing of cancer research studies in last recent years. Although epigenetic effects of these elements have more prominent role than their genetics effects, these elements are able to alter the pattern of cancerrelated genes' expression profiles, too. Therefore, an understanding of the underlying epigenetically mechanisms of these trace elements and the compounds, which could reduce their toxicities or the number of cancer cases due to these elements in the areas that are contaminated with these metals. Perhaps the toxic effects of these elements in many regions are predictable, but antioxidant supplements may eliminate the reactive oxygen species as leading effects of these elements. The present review article is the compilation of various studies dealt with epigenetic effects of carcinogens on human health.
\end{abstract}

Keywords: Cancer prevention, Cancer stem cell, Drinking-water, Epigenetic effects of carcinogens, Heavy metal.

\section{INTRODUCTION}

Cancer is a leading cause of morbidity, mortality, and premature death worldwide [1]. While cancer was previously a problem principally of the industrially developed countries, it increasingly is a problem in the developing ones. Today, half of the world's newly diagnosed cancers and over $70 \%$ of all cancer deaths occur in middle and low-income countries [2]. This persistent and growing burden of cancer in the world's population's warrants heightened public health attention. Prevention, early detection, and therapy have all proven effective in controlling certain types of cancer and in reducing the burden of premature death and advanced disease [3-6]. The prevalence and mortality due to multifactorial polygenic diseases such as varieties of cancer vary depending upon genetic susceptibility and environmental precursors because they have identifiable mendelian subsets. Rapid changes in diet and lifestyle may influence heritability of the variant phenotypes that are dependent on the nutraceutical supplementation for their expression $[5,6]$. It is possible to recognize the interaction of specific nutraceuticals, with the genetic code possessed by all nucleated cells [6]. In

*Address correspondence to this author at the Department of Biotechnology, College of Engineering \& Technology, IFTM Campus, Delhi Road, Moradabad 244 001, UP, India; Tel: +91-591-2360817;

Fax: +91-591-2360818; E-mail: sanjaymishra66@gmail.com many countries, however, these well established approaches to cancer control have not been applied to their full potential and in many countries are not applied at all. Furthermore, great disparities still exist in cancer control in relation to gender, race, ethnicity, and socio-economic status.

Till date, many carcinogens have already been identified and the relevant information with regard to these agents is available. However, humans use many food and beverage items, assuming that they are safe. One example is the potentially harmful presence of heavy metals that can cause serious health problems. People may be exposed to heavy metals over the course of their lifetime. The heavy metals in drinking-water pose the greatest threat to public health in this regard. This necessitates setting suitable quality control procedures. The main source of heavy metals in drinking-water is contamination of surface and ground waters by industrial sewage and agricultural run-off [7]. In the areas that the water distribution network is made of alloys containing heavy metals, some people may not afford bottled- or mineral water with controlled heavy metal concentrations and they consume tap water, therefore the possibility of contamination of drinking-water with heavy metals greatly increases [8]. According to some WHO reports, the concentration of these elements in ground water is high in several countries including Bangladesh, India, and Argentina [9, 10]. Heavy metals in drinking-water are toxic and can easily enter the body. 
The genetic and epigenetic effects of these elements are associated with an increased risk of different cancer types [11].

Epigenetic mechanisms play an equally important if not a more prominent role than genetic events in carcinogenesis. These effects occur most frequently during the early stages of tumor development. Epigenetic events include reversible modification of histone proteins and $\mathrm{CpG}$ islands of gene promoters that affect not only gene expression of germ and somatic cells, but also cause indirect gene-sequence changes $[12,13]$.

CpG islands (5'-CG-3' sequence) exist in about $40 \%$ of mammalian genes. Hypermethylation or hypomethylation of C5 position of the cytosine base are involved in the inhibition of expression of tumor suppressor genes or the increase of the oncogene expression, both of which contribute to cancer development and progression [14]. Gene silencing can also take place through methylation of lysine 9 in histone- $\mathrm{H} 3$ (H3-K9), which results in a cascade of clustering of several proteins including HP1 protein, SUV39H1 histone methyltransferase, histone deacetylases, DNA Methyl transferases, and finally methyl-C binding proteins (MBD) [15-17]. Methylated cytosine may be spontaneously deaminated to produce a thymine, resulting in a specific transition mutation in $\mathrm{CpG}$ islands, for example in the $\mathrm{TP}_{53}$ tumor suppressor gene as a guard of genome. In addition, hypermethylation of histone proteins causes changes in the chromatin configuration, predisposing cells to allelic loss at a specific locus in the chromosomes [18]. Such genetic and epigenetic alterations in growth-control genes such as DNA-repair genes, tumor suppressor genes, oncogenes, apoptotic genes, combine to determine the cellular phenotype and differentiation $[13,19]$.

In ranking the carcinogens, heavy metals have been classified by the International Agency for Research on Cancer (IARC) and Environmental Protection Agency (EPA) as the first group, except for selenium that has been listed within group 3 (not carcinogen to humans) of the IARC classification [20].

The goal of this review is the introduction and comparison of the epigenetic effects caused by the following elements in cancer-concerned genes in biological systems, including in human and show that the incidence of cancer can be reduced by adopting prevention behavior especially in terms of drinking-water taking into consideration of the following elements and their conjugative:

\section{ALUMINIUM}

The compounds of this element have a wide range of applications in different industries, including cosmetics, and food additives [21]. Aluminum-induced carcinogenesis is related to its ability to bind to the estrogen receptor and mimic estrogen functions, therefore its named metalloestrogen [22]. Metalloestrogen triggers expression in genes that contain estrogen responsive-element (ERE) on their promoters. In mammary gland cells, this gives rise to an increase in the number of divisions of breast cells, thus increasing replication errors in cancer-related genes [23]. It has been shown that if antiperspirants containing aluminum applied on the skin around the underarm and breast areas are not effectively washed, some aluminum salts remains in the area. This gives rise to continuous exposure, and enhances the risk of breast cancer [24].

There are two different groups of estrogen receptors (ER). The first group exist in cytosol/nucleus (ER- $\alpha$ and ER$\beta$ ) and act as transcription factors by directly binding to ERE, while the second one exists in plasma membrane as transmembrane G-protein coupled receptors. These ERs can also regulate gene expression via interaction with other transcription factors, without directly binding to ERE. Plasma membrane located ER46 is involved in endothelial nitric oxide synthase (eNOS) phosphorylation and rapid nitric oxide (NO) release via phosphatidyl inositol 3-kinase in endothelial cells. Another plasma membrane located ER family called ER66 regulates reporter gene expression [22]. Aluminum can bind to both nuclear and membrane ERs, and ERE; as a result, it can activate both ER signal transductions. Therefore, as expected, $\mathrm{Al}^{3+}$ treatment results in intracellular NO generation [25].

In addition to breast carcinogenesis, estrogen can activate telomerase gene expression as a gene containing ERE, in ER- $\alpha$ positive cell, but not in ER negative cells, these results in endometrial cancer [26]. The epigenetic effects of aluminum take place through the binding of trivalent $\left(\mathrm{Al}^{3+}\right)$ to the phosphate groups of double stranded DNA under physiologic $\mathrm{pH}$, thus changing DNA topology from $\mathrm{B}$ to $\mathrm{Z}$ in $(\mathrm{CCG})_{12}$ repeat regions [27]. The expansion of the triplet repeats is named "dynamic mutation", and may be localized both in coding and non-coding regions. A minimum of 5-10 triplet-repeats increases the probability of hairpin formations, mainly in the lagging strand. Movement of DNA polymerase along the hairpin structure leads to replication slippage and genomic instability, causing deletion mutations. Expansion of more than 200 copies of these repeats leads to excessive methylation of cytosines in the promoter of FMR1 gene which results in fragile $\mathrm{X}$ syndrome [28].

\section{ARSENIC}

Arsenic is mostly known as an epigenetic carcinogen metalloid when in the form of an inorganic compound. Trivalent arsenite $\left(\mathrm{As}^{+3}\right)$ has more carcinogenic properties than the pentavalent arsenate $\left(\mathrm{As}^{+5}\right)[29,30]$. Trivalent arsenic can bind with high affinity to thiol groups of proteins and reduced glutathione (GSH) [31]. Long time uptake of drinking-water containing low levels of arsenite, induces carcinogenesis in skin, lung, bladder, and kidney tissues, resulting from alteration in multiple signaling pathways [32]. The risk of bladder cancer in people drinking water with an arsenic level above $100 \mathrm{ppb}$ increases over 15 times compared with people living in areas with less than $10 \mathrm{ppb}$ [33].

Arsenic is methylated for detoxification and excretion from the body. It is exactly this reaction that gives rise to the carcinogenic properties of arsenic through the epigenetic transformations. This is contrary to the general belief that considers the methylation as a way for detoxification. The toxicity of monomethyl arsenic (MMAs) and dimethyl arsenic (DMAs) is more than arsenite [29, 31]. Arsenic methylation occurs by Glutatione S-transferase (GST), arsenic III methyltransferase (AS3MT), and S-adenosyl methionine (SAM). These enzymes compete with DNA methyltrans- 
ferase (DNMT) for DNA methylation, hence, inhibiting DNA methyltransferase indirectly, and inducing the reactivation of silenced tumor suppressor genes [5, 34]. Exposure to arsenic induces the ROS formation (through its reduction) as an unavoidable reaction of normal cell metabolism [35]. ROS, acting as a second messenger, are involved in the activation of PI3K/Akt pathway and the subsequent induction of transcription factor hypoxia inducible factor-1 (HIF-1 $\alpha$ ) but not HIF-1 $\beta$, and vascular endothelial growth factor (VEGF) induction [36-38].

Another important mechanism of arsenic induced carcinogenesis is through enhancing the genotoxicity of other carcinogens, including ultraviolet radiation (UVR), ionizing radiation, alkylating agents, or oxidants. UVR induces nonmelanoma skin cancer. Strands of DNA exposed to photons of UVA and UVB break, and cyclobutane pyrimidine dimers (CPDs) are formed [39, 40]. UVRs can activate a zinc-finger protein family poly (ADP-ribose) polymerase (PARP), particularly one member of this family named PARP-1, has an important role in the regulation of nucleotide excision repair (NER). CPDs have been identified in p53 and PTCH tumor suppressor genes and ras oncogenes [41, 42].

Arsenite stimulates inducible nitric oxide synthase (iNOS) expression and NO production through mammalian mitogen-activated protein kinases $\mathrm{p} 38$ and activation of nuclear transcription factor-kappa B $(\mathrm{NF}-\kappa \mathrm{B})$ [43]. Between 40 to $60 \%$ of arsenic intake is excreted into the urine [44]. A major proportion (60-80\%) of urinary arsenic is composed of dimethylated arsenic [45].

\section{CHROMIUM}

Trivalent chromium is an epigenetic carcinogen factor since it can form stable compounds with macromolecules such as DNA and cysteine residue of proteins and glutathione [46]. The trivalent form of chromium cannot pass the cell membrane; however, the hexavalent salts are able to enter the cell and are converted to the trivalent form [47]. Thus, depending on the situation, reducing agents can affect carcinogenic properties of chromium and inside the cell, chromium (VI) can be converted to a carcinogen. During $\mathrm{Cr}$ (VI) reduction, many compounds such as oxygen radicals, DNA inter-strand cross links (ICLs), and single-strand breaks (SSBs) may form. ICLs act as physical barriers to DNA replication and transcription events, thus inducing apoptosis [48]. The chromium carcinogenicity, particularly in lung epithelial cells and fibroblasts, is imposed through hypermethylation of CYP1a1 promoter. Chromium recruits histone deacetylase 1 (HDAC1) and DNMT1, especially to CYP1a1 promoter, and this assembly recruits BP1 and inhibits CYP1a1 gene expression [49]. CYP1A1 is important in the metabolism of carcinogens such as polycyclic aromatic hydrocarbons (PAHs) and heterocyclic amines that are widely distributed widely in our environment through automobile exhausts, cigarette smoke, charcoal-broiled cooking, and industrial waste. In contrast to other cytochrome P450 enzymes such as epoxide hydrolase and dihydrodiol dehydrogenase that are involved in PAH- and Benzo(a)pyreneinduced carcinogenesis, CYP1A1 inhibits PAH carcinogenesis. Thus, inhibition of CYP1A1 by chromium leads to the production of a PAH [50]. PAHs have an important role in the activation of cytosolic ligand-activated transcription fac- tor named aromatic hydrocarbon receptor (AhR) [51]. After formation, the PAH-AhR complex is transferred into the nucleus. In the nucleus, PAH is detached from the complex and AhR binds to its nuclear partner, Arnt. This new complex acts as a transcription factor and interacts with DRE of CYP1A1 gene, leading to the activation of CYP1A1 gene expression, thus causing bioactivation of exogenous procarcinogens of both hepatocellular and lung carcinomas [52].

It is interesting that PAH through binding to transcription factor AhR, activates CYPlal gene expression, and CYP1A1 inhibits PAH carcinogenesis, but in the presence of $\mathrm{Cr}$, the promoter of CYP1a1 is inactivated and PAH can act as carcinogens [49]. $\operatorname{Benzo}(\alpha)$ pyrene is also a member of polycyclic aromatic hydrocarbon (PAHs) family that is metabolically transformed from its pro-carcinogenic status to the carcinogenic metabolite (BP-7,8-dihydrodiol-9,10epoxide (BPDE)), that can bind covalently to DNA and form BPDE-DNA adducts and reactive oxygen species. BPDE activates apoptosis through p53 -independent and dependent manner [53]. P53 dependent Cr-induced apoptosis takes place by increasing p53 phosphorylation at serine 392, as well as up-regulation of pro-apoptotic gene bcl-XS, and caspase-7, and down-regulation of several anti-apoptotic genes from Bcl2-family (bcl-W and bcl-XL), and bax. These apoptotic events result in the destruction of the mitochondria and release of cytochrome c [54-57]. Moreover, $\mathrm{Cr}$ induces the ATM protein production, which phosphorylates and activates $\mathrm{Chk}_{2}$ protein. The phosphorylated Chk2 in turn phosphorylates and activates p53. The phosphorylated p53 does not bind to MDM2 protein $[13,57]$. Cr exposure at very high concentrations activates all subclasses of MAPK through phosphorylation; therefore, $\mathrm{Cr}$ acts as a MAPK kinase and increases survival/proliferation in a dose-dependent manner. This function is associated with its ability in ROS generation $[58,59]$.

\section{NICKEL}

Water-insoluble nickel compounds including nickel sulfides, disulfides, and oxides readily enter the cell and are very potent carcinogens [60]. In contrast, water-soluble nickel compounds including acetate, chloride, nitrate, and sulfate do not enter the cells as readily as water-insoluble nickel compounds [61]. The increase in the usage of nickel compounds and the spread of nickel due to its dissolution from nickel ore-bearing rocks are the main causes of nickel presence in the environment. The primary source of nickel in drinking-water is the leaching of metals in water network [62]. However, food is the major source of nickel exposure in the non-smoking, non-occupationally exposed population, but nickel absorption from water, was significantly higher than absorption of nickel from beverages like tea, coffee, or orange juice and milk [63]. $\mathrm{Ni}^{2+}$ induces carcinogenesis through several processes including DNA hypermethylation (H3K9 mono- and dimethylation), DNMT inhibition, DNA mutation, ROS generation, inhibiting histone $\mathrm{H} 2 \mathrm{~A}, \mathrm{H} 2 \mathrm{~B}, \mathrm{H} 3$ and $\mathrm{H} 4$ acetylation, converting the tumor suppressor genes to the heterochromatin, and substantial increases of the ubiquitination of $\mathrm{H} 2 \mathrm{~A}$ and $\mathrm{H} 2 \mathrm{~B}$ [64]. Therefore, nickel plays an important role in the suppression or silencing of genes [65].

Nickel binds to DNA in different positions. It binds to phosphate backbone of DNA in place of $\mathrm{Mg}$ and promotes 
Table 1. Toxic Metals and their Reactive Forms

\begin{tabular}{|l|l|}
\hline Al & $\begin{array}{l}\text { Binding of trivalent Aluminium ion }\left(\mathrm{Al}^{3+}\right) \text { to the phosphate groups of double stranded DNA under physiologic pH, thus changing DNA } \\
\text { topology from B to } \mathrm{Z} \text { in }(\mathrm{CCG})_{12} \text { repeat regions }\end{array}$ \\
\hline $\mathbf{C d}$ & All forms are toxic and need attention \\
\hline $\mathbf{C r}$ & $\begin{array}{l}\text { Trivalent chromium is an epigenetic carcinogen factor since it can form stable compounds with macromolecules such as DNA and cysteine } \\
\text { residue of proteins and glutathione. The trivalent form of chromium cannot pass the cell membrane; however, the hexavalent salts are able to } \\
\text { enter the cell and are converted to the trivalent form }\end{array}$ \\
\hline $\mathbf{N i}$ & $\mathrm{Ni}^{2+}$ induces carcinogenesis through the suppression or silencing of genes \\
\hline $\mathbf{S e}$ & $\begin{array}{l}\text { Selenium, is detoxified by methylation through S-adenosylmethionine pathway, competition between arsenic, selenium and DNMT1 for } \\
\text { methyl donated by S-adenosylmethionine leads to DNA hypomethylation, and an increase in Selenium retention in tissues as biomagnificant. }\end{array}$ \\
\hline $\mathbf{P b}$ & Organic forms are more toxic and easily absorbed by the gastrointestinal tract \\
\hline $\mathbf{A s}$ & Inorganic arsenate [As( +5$)]$ or [As(+3)] are more toxic \\
\hline $\mathbf{H g}$ & Hg(II) Organomercurials mainly methylmercury, biologically magnified \\
\hline
\end{tabular}

the conversion of suppressor genes to the heterochromatin [66]. Moreover, it's binding to histone $\mathrm{H} 4$ leads to the inhibition of lysine acetylation, and subsequently DNA hypermethylation [67]. These events play an important role in silencing of tumor suppressor genes and the other genes that are involved in carcinogenesis pathways.

\section{SELENIUM}

Selenium is an essential trace element with a narrow range between toxic and therapeutic doses; its activity is therefore highly dose dependent. Enzymes containing selenium such as glutathione peroxidase like other antioxidant elements can protect body from oxidative damage and reduce the risk of cancer incidence and mortality through several pathways such as apoptosis, and alteration of some collagen types [68].

Since selenium, like arsenic is detoxified by methylation through S-adenosylmethionine pathway, competition between arsenic, selenium and DNMT1 for methyl donated by $\mathrm{S}$-adenosylmethionine leads to DNA hypomethylation, and an increase in arsenic retention in tissues [69]. Organic selenium compounds such as selenomethionine, Se-methylselenocysteine (Se-MSC), and particularly Selenocystine $(\mathrm{SeC})$, have shown more anticarcinogenic activity than inorganic compounds in lung cancer model systems. However, in contrast to selenomethionine, selenocystine decreases cellular reduced thiol agents like $\mathrm{N}$-acetylcysteine (NAC) and GSH, thus increasing the ROS formation [70].

Selenium-containing proteins can induce apoptosis pathway through caspase activation. But, selenite, $\mathrm{SeC}$, and selenomethionine mostly activate apoptosis by caspaseindependent pathways through p53 activation and antiapoptotic inactivation and release of cytochrome $\mathrm{c}$ from mitochondria as follows. First, these compounds increase production of reactive oxygen species. ROS-mediated modified products such as DSBs, are detectd by ATM and ATR proteins, which in turn can activate p53 in MCF-7 human breast cancer cells and human prostate cancer. These DSBs can even synergistically increase the intracellular ROS production. Second, they induce p53 phosphorylation at $\operatorname{Ser}_{15}$,
$\mathrm{Ser}_{20}$, and $\operatorname{Ser}_{392}$ residues, thus decreasing p53-MDM2 protein interaction and p53 stability [71].

The Se-MSC shows its anti-carcinogenic activity through down regulation of some extracellular matrix proteins such as collagen type $\mathrm{I}$ alpha $1\left(\mathrm{COL}_{1} \mathrm{~A} 1\right), \mathrm{COL}_{1} \mathrm{~A}_{2}$ and $\mathrm{COL}_{7} \mathrm{~A}_{1}$, and up-regulation of $\mathrm{COL}_{6} \mathrm{~A}_{1}$ and $\mathrm{COL}_{4} \mathrm{~A}_{5}$ genes in human prostate cell line [72].

\section{CONCLUDING REMARKS}

Conclusively, based on experimental studies, the heavy metals ability in ROS and NF-kB production, also human genetic differences through polymorphisms in GST, metallothioneins and heavy metal methyltransferase genes induce carcinogenesis. Many of these results may eliminate by daily antioxidant usage [73]. This review shows that these heavy metals are carcinogen (Table 1), particularly epigenetic carcinogen and might be solely responsible for tumors presentation and progression. The ongoing research works throw more light onto new insights and biochemical and molecular mechanisms involved in the development of pathological conditions in human.

\section{ACKNOWLEDGEMENTS}

The authors are grateful to Prof. R. M. Dubey (Managing Director) and Prof. A. Srivastav (Director), CET, IFTM Campus, Moradabad, U.P., India for providing the necessary facilities and encouragement. Besides, Prof. B.N. Basu is duly acknowledged for critical suggestions.

\section{REFERENCES}

[1] Parkin DM, Bray F, Ferlay J, Pisani P. Global cancer statistics 2002. CA Cancer J Clin 2005; 55: 74-108

[2] Kanavos P. The rising burden of cancer in the developing world. Ann Oncol 2006; 17(8): viii15-viii23.

[3] Curry SJ, Byers T, Hewitt M, Eds. Fulfilling the potential of cancer prevention and early detection. Washington, D.C.: National Academy Press; 2003.

[4] Nanda S, Mishra S, Varshney VP, Singh RB. Cytotoxic effect of Syzgium aromaticum extract and gemcitabine on human cervical cancer cell line. Open Nutra J 2010; 3: 69- 75.

[5] Mishra S, Singh RB, Dwivedi SP, et al. Effects of nutraceuticals on genetic expressions. Open Nutra J 2009; 2: 70-80. 
[6] Mudgal V, Madaan N, Mudgal A, Singh RB. Effect of toxic metals on human health. Open Nutra J 2010; 3: 94-7.

[7] Karavoltsos S, Sakellari A, Mihopoulos N, Dassenakis M, Scoullos MJ. Evaluation of the quality of drinking-water in regions of Greece. Desalination 2008; 224: 317-29.

[8] Leivadara SV, Nikolaou AD, Lekkas TD. Determination of organic compounds in bottled waters. Food Chem 2008; 108: 277-86

[9] WHO. World Health Organization, Geneva. Environmental Health Criteria 1987; No.58.

[10] WHO. Arsenic in Drinking-water. Background document for development of WHO Guidelines for Drinking-water Quality 2003

[11] Bower JJ, Leonard SS, Shi X. Conference overview: Molecular mechanisms of metal toxicity and carcinogenesis. Mol Cell Biochem 2005; 279: 3-15.

[12] Jones PA, Baylin SB. The fundamental role of epigenetic events in cancer. Nat Rev Genet 2002; 3: 415-28.

[13] Vaziri GA, Mohammadi A, Heidari M. Molecular Genetics of Cancer. Samer, Tehran, Iran, 2007; ISBN: 978-964-91351-0-6.

[14] Kinzler KW, Vogelstein B. Cancer-susceptibility genes. Gatekeepers and caretakers. Nature 1997; 386: 761-63.

[15] Tamaru H, Selker EU. A histone H3 methyltransferase controls DNA methylation in Neurospora crassa. Nature 2001; 414: 277-83

[16] Jackson JP, Lindroth AM, Cao X, Jacobsen SE. Control of CpNpG DNA methylation by the kryptonite histone $\mathrm{H} 3$ methyltransferase. Nature 2002; 416: 556-60.

[17] Vogelstein B, Kinzler KW. Cancer genes and the pathways they control. Nat Med 2004; 10: 789-99.

[18] Egger G, Liang G, Aparicio A, Jones PA. Epigenetics in human disease and prospects for epigenetic therapy. Nature 2004; 429: 457-63.

[19] Mohammadi A,Vaziri Gohar A, Shakibaie MR. Mutations in Tumor suppressor TP53 gene in formalin- fixed, paraffin embedded tissues of squamous cell carcinoma (SCC) of lung cancer. Am J Biochem Biotechnol 2008; 4(1): 1-6.

[20] IARC. Monograph on Chromium, Nickel and Welding, International Agency for Research on Cancer, Lyon, France, 1989; Vol. 49.

[21] Laden K, Felger CB. Antiperspirants and deodorants. In Cosmetic Science and Technology Series. New York, Marcel Dekker 1988; Volume 7.

[22] Darbre PD. Aluminium, antiperspirants and breast cancer. J Inorgan Biochem 2005; 99: 1912-19.

[23] Sun X, Fontaine JM, Bartl I, Behnam B, Welsh MJ, Benndorf R. Induction of Hsp22 (HspB8) by estrogen and the metalloestrogen cadmium in estrogen receptor-positive breast cancer cells. Cell Stress Chaperones 2007; 2: 307-19.

[24] Stellman SD, Djordjevic MV, Britton JA, et al. Breast cancer risk in relation to adipose concentrations of organochlorine pesticides and polychlorinated biphenyls in Long Island, New York. Cancer Epidemiol Biomarks Prev 2000; 9: 1241-49.

[25] Satoh E, Yasuda I, Yamada T, Suzuki Y, Ohyashiki T. Involvement of NO generation in aluminum-induced cell death. Biol Pharm Bull 2007; 30: 1390-94.

[26] Harley B. Telomerase and cancer therapeutics. Nat Rev Cancer 2008; 8: 167-79.

[27] Zhang RY, Lui Y, Pang DW, Cai RX, Qi YP. Spectroscopic and voltammetric study on the binding of aluminium (III) to DNA. Anal Sci 2002; 18: 761-7.

[28] Lukusa T, Fryns JP. Human chromosome fragility. Biochim Biophys Acta 2008; 1779: 3-16.

[29] Patterson TJ, Ngo M, Aronov PA, Reznikova TV, Green PG, Rice RH. Biological activity of inorganic arsenic and antimony reflects oxidation state in cultured human keratinocytes. Chem Res Toxicol 2003; 16: 1624-31.

[30] Alkahtani S. Antioxidation and hypomethylation effects on genotoxicity and programmed cell death induced in mice somatic cells by arsenic trioxide. J Biol Sci 2009; 9(7): 721-9.

[31] Suzuki KT, Katagiri A, Sakuma Y, Ogra Y, Ohmichi M. Distributions and chemical forms of arsenic after intravenous administration of dimethylarsinic and monomethylarsonic acids to rats. Toxicol Appl Pharmacol 2004; 198: 336-44.

[32] Jensen TJ, Wozniak RJ, Eblin KE, Wnek SM, Gandolfi AJ, Futscher BW. Epigenetic mediated transcriptional activation of WNT5A participates in arsenical-associated malignant transformation. Toxicol Applied Pharmacol 2009; 15; 235(1): 39-46.
[33] Vahter M. Mechanisms of arsenic biotransformation. Toxicology 2002; 181: 211-7.

[34] Huang S. Histone methyltransferases, diet nutrients and tumour suppressors. Nat Rev Cancer 2002; 2: 469-76.

[35] Galanis A, Karapetsas A, Sandaltzopoulos R. Metal induced carcinogenesis, oxidative stress and hypoxia signaling. Mutat Res 2008 a; 674(1-2): 31-5.

[36] Sharma V, Kalim S, Sivastava MK, Nanda S, Mishra S. Oxidative stress and coxsackievirus infections as mediators of beta cell damage: a review. Sci Res Essay 2009; 4 (2): 42-58

[37] Galaris D, Skiada V, Barbouti A. Redox signaling and cancer: The role of "labile" iron. Cancer Lett 2008b; 266: 21-9.

[38] Gao N, Shen L, Zhang Z, et al. Arsenite induces HIF-1 $\alpha$ and VEGF through PI3K, Akt and reactive oxygen species in DU145 human prostate carcinoma cells. Mol Cell Biochem 2004; 255(1-2): 33-45.

[39] Melnikova VO, Ananthaswamy HN. Cellular and molecular events leading to the development of skin cancer. Mutat Res 2005; 571: 91-106.

[40] Ravanat JL, Douki T, Cadet J. Direct and indirect effects of UV radiation on DNA and its components. J Photochem Photobiol 2001; 63: 88-102.

[41] Rossman TG, Uddin AN, Burns FJ. Arsenite is a cocarcinogen with solar ultraviolet radiation for mouse skin: an animal model for arsenic carcinogenesis. Toxicol Appl Pharmacol 2001; 176(1): 64-71.

[42] Rossman TG, Uddin AN, Burns FJ. Arsenite cocarcinogenesis: an animal model derived from genetic toxicology studies. Environ Health Perspect 2002; 110: 749-52.

[43] Ding W, Hudso LG, Sun X, Feng C, Liu KJ. As (III) inhibits ultraviolet radiation-induced cyclobutane pyrimidine dimer repair via generation of nitric oxide in human keratinocytes. Free Radiat Biol Med 2008; 45: 1065-72.

[44] Fujihara J, Fujii Y, Agusa T. Ethnic differences in five intronic polymorphisms associated with arsenic metabolism within human arsenic ( +3 oxidation state) methyltransferase (AS3MT) gene. Toxicol Appl Pharmacol 2009; 234 (1): 41-6.

[45] Vahter M. Genetic polymorphism in the biotransformation of inorganic and its role in toxicity. Toxicol Lett 2000; 112-113: 209-17.

[46] Zhitkovich A, Voitkun V, Costa M. Glutathione and free amino acids form stable complexes with DNA following exposure of intact mammalian cells to chromate. Carcinogenesis 1995; 16: 90713.

[47] Alexander J, Aaseth J. Uptake of chromate in human red blood cells and isolated rat liver cells: The role of the anion carrier. Analyst 1995; 120: 931-3.

[48] Schnekenburger M, Peng L, Puga A. HDAC1 bound to the Cyp1a1 promoter blocks histone acetylation associated with Ah receptormediated trans-activation. Biochim Biophys Acta 2007; 1769: 56978.

[49] Wei YD, Tepperman K, Huang MY, Sartor MA, Puga A. Chromium inhibits transcription from polycyclic aromatic hydrocarboninducible promoters by blocking the release of histone deacetylase and preventing the binding of p300 to chromatin. J Biol Chem 2004; 279: 4110-19.

[50] Wu JP, Chang LP, Yao HT, et al. Involvement of oxidative stress and activation of aryl hydrocarbon receptor in elevation of CYP1A1 expression and activity in lung cells and tissues by arsenic: An in vitro and in vivo study. Toxicol Sci 2008; 107: 385-93.

[51] Nebert DW, Roe AL, Dieter MZ, Solis WA, Yang Y, Dalton TP. Role of the aromatic hydrocarbon receptor and $[\mathrm{Ah}]$ gene battery in the oxidative stress response, cell cycle control and apoptosis. Biochem Pharmacol 2000; 59: 65-85.

[52] Li R, Shugart YY, Zhou W, et al. Common genetic variations of the cytochrome P450 1A1 gene and risk of hepatocellular carcinoma in a Chinese population. Eur J Cancer 2009; 45: 1239-47.

[53] Drukteinis JS, Medrano T, Ablordeppey EA, Kitzman JM, Shiverick KT. Benzo[a]pyrene, but Not 2,3,7,8-TCDD, induces G2/M cell cycle arrest, p21CIP1 and p53 phosphorylation in human choriocarcinoma JEG-3 cells: A distinct signaling pathway. Placenta 2005; 26: S87-95.

[54] Blankenship LJ, Manning FC, Orenstein JM, Patierno SR. Apoptosis is the mode of cell death caused by carcinogenic chromium. Toxicol Appl Pharmacol 1994; 126: 75-83.

[55] Carlisle DL, Pritchard DE, Singh J, et al. Apoptosis and P53 induction in human lung fibroblasts exposed to chromium(VI): effect of ascorbate and tocopherol. Toxicol Sci 2000; 55(1): 60-68. 
[56] Ceryak S, Zingariello C, O'Brien T, Patierno SR. Induction of proapoptotic and cell cycle-inhbiting gene in chromium (VI)-treated human lung fibroblasts: lack of effect of ERK. Mol Cell Biochem 2004; 255: 139-49.

[57] Ha L, Ceryak S, Patierno SR. Chromium (VI) activates ATM: requirement of ATM for both apoptosis and recovery from terminal growth arrest. J Biol Chem 2003; 278: 17885-94.

[58] Gao N, Jiang BH, Leonard SS, et al. p38 signaling-mediated hypoxia-inducible factor $1 \alpha$ and vascular endothelial growth factor induction by $\mathrm{Cr}$ (VI) in DU145 human prostate carcinoma cells. J Biol Chem 2002; 277: 45041-8.

[59] Thomas G. MAP kinase by any other name smells just as sweet. Cell 1992; 68: 3-6.

[60] Dunnick JK, Elwell MR, Radovsky AE, JM, et al. Comparative carcinogenic effects of nickel subsulfide, nickel oxide, or nickel sulfate hexahydrate chronic exposures in the lung. Cancer Res 1995; 55: 5251-6.

[61] Abbracchio MP, Heck JD, Costa M. The phagocytosis and transforming activity of crystalline metal sulfide particles are related to their negative surface charge. Carcinogenesis 1982; 3: 17580 .

[62] WHO. Nickel in Drinking-Water. Background document for development of WHO guidelines for drinking-water quality, 2005.

[63] Nielsen GD, Søderberg U, Jørgensen PJ, Templeton DM, Rasmussen SN. Absorption and retention of nickel from drinking-water in relation to food intake and nickel sensitivity. Toxicol Applied Pharmacol 1999; 154(1): 67-75.

[64] Ke Q, Ellen TP, Costa M. Nickel compounds induce histone ubiquitination by inhibiting histone deubiquitinating enzyme activity. Toxicol Applied Pharmacol 2008; 228: 190-9.
[65] Lee YW, Broday L, Costa M. Effects of nickel on DNA methyltransferase activity and genomic DNA methylation levels. Mutat Res 1998; 415: 213-8.

[66] Cangul H, Broday L, Salnikow K, et al. Molecular mechanisms of nickel carcinogenesis. Toxicol Lett 2002; 127: 69-75.

[67] Broday L, Peng W, Kuo MH, Salnikow K, Zoroddu M, Costa M. Nickel compounds are novel inhibitors of histone $\mathrm{H} 4$ acetylation. Cancer Res 2000; 60: 238-41.

[68] Rayman MP. The importance of selenium to human health. Lancet 2000; 356: 233- 41.

[69] Xiang N, Zhao R, Song G, Zhong W. Selenite reactivates silenced genes by modifying DNA methylation and histones in prostate cancer cells. Carcinogenesis 2008; 29: 2175-81.

[70] Zou Y, Niu P, Yang J, Yuan J, Wu T, Chen X. The JNK signaling pathway is involved in sodium-selenite-induced apoptosis mediated by reactive oxygen in HepG2 cells. Cancer Biol Ther 2008; 7: 68996.

[71] Chen T, Wong YS. Selenocystine induces caspase-independent apoptosis in MCF-7 human breast carcinoma cells with involvement of p53 phosphorylation and reactive oxygen species generation. Int J Biochem Cell Biol 2008; 41(3): 666-76.

[72] Hurst R, Elliott RM, Goldson AJ, Fairweather-Tait SJ. Semethylselenocysteine alters collagen gene and protein expression in human prostate cells. Cancer Lett 2008; 269(1): 117-26.

[73] Evans J. Antioxidant supplements to prevent or slow down the progression of AMD: A systematic review and meta-analysis. Eye 2008; 22: 751-60. 